\title{
Influence of Chitosan, Salicylic Acid and Jasmonic Acid on Phenylpropanoid Accumulation in Germinated Buckwheat (Fagopyrum esculentum Moench)
}

\author{
Chang Ha Park ${ }^{1,+}$, Hyeon Ji Yeo ${ }^{1,+}$, Ye Eun Park ${ }^{1}$, Se Won Chun ${ }^{1}$, Yong Suk Chung ${ }^{2}$, \\ Sook Young Lee ${ }^{3, *}$ and Sang Un Park ${ }^{1, *}$ \\ 1 Department of Crop Science, Chungnam National University, 99 Daehak-ro, Yuseong-gu, \\ Daejeon 34134, Korea; parkch804@gmail.com (C.H.P.); guswl7627@gmail.com (H.J.Y.); \\ yeney1996@cnu.ac.kr (Y.E.P.); seaw613@cnu.ac.kr (S.W.C.) \\ 2 Department of Plant Resource and Environment, Jeju National University, 102 Jejudaehak-ro, Jeju-si, \\ Jeju Special Self-Governing Province 63243, Korea; yschung@jejunu.ac.kr \\ 3 Marine Bio Research Center, Chosun University, 61-220 Myeongsasimni, Sinji-myeon, Wando-gun, \\ Jeollanamdo 59146, Korea \\ * Correspondence: seedbank@chosun.ac.kr (S.Y.L.); supark@cnu.ac.kr (S.U.P.); Tel.: +82-10-8610-6739 (S.Y.L.); \\ +82-42-821-5730 (S.U.P.); Fax: +82-61-555-1260 (S.Y.L.); +82-42-822-2631 (S.U.P.) \\ + These authors contributed equally to this work.
}

Received: 8 February 2019; Accepted: 30 April 2019; Published: 6 May 2019

\begin{abstract}
The present study investigated the effects of jasmonic acid (JA), chitosan, and salicylic acid (SA) on the accumulation of phenolic compounds in germinated buckwheat. A total of six phenolics were detected in the buckwheat treated with different concentrations of SA (50, 100, and $150 \mathrm{mg} / \mathrm{L})$, JA (50, 100, and $150 \mu \mathrm{M})$, and chitosan (0.01, 0.1, and $0.5 \%)$ using high-performance liquid chromatography (HPLC). The treatment with $0.1 \%$ chitosan resulted in an accumulation of the highest levels of phenolic compounds as compared with the control and the 0.01 and $0.5 \%$ chitosan treatments. The treatment with $150 \mu \mathrm{M}$ JA enhanced the levels of phenolics in buckwheat sprouts as compared with those observed in the control and the 50 and $100 \mu \mathrm{M} \mathrm{JA-treated} \mathrm{sprouts.} \mathrm{However,}$ the SA treatment did not affect the production of phenolic compounds. After optimizing the treatment concentrations of elicitors (chitosan and JA), a time-course analysis of the phenolic compounds detected in the germinated buckwheat treated with $0.1 \%$ chitosan and $150 \mu \mathrm{M} \mathrm{JA}$ was performed. Buckwheat treated with $0.1 \%$ chitosan for $72 \mathrm{~h}$ showed higher levels of phenolic compounds than all control samples. Similarly, the germinated buckwheat treated with JA for 48 and $72 \mathrm{~h}$ produced higher amounts of phenolic compounds than all control samples. This study elucidates the influence of SA, JA, and chitosan on the production of phenolic compounds and suggests that the treatment with optimal concentrations of chitosan and JA for an optimal time period improved the production of phenolic compounds in germinated buckwheat.
\end{abstract}

Keywords: germinated buckwheat; elicitors; phenolic compounds; jasmonic acid; chitosan

\section{Introduction}

Fagopyrum esculentum Moench (common buckwheat), belonging to the Polygonaceae family, is an important pseudocereal cultivated and consumed in East Asian countries. It has high agricultural and medicinal values [1]. It contains various minerals (magnesium, copper, zinc, and manganese), fiber, and a large quantity of rutin [2], which exhibits anti-allergic [3], cytoprotective [4], anti-thrombotic [5], and anti-carcinogenic activities [6]. Furthermore, rutin and its related flavonoids in buckwheat have 
various health effects. For example, it functions as an inhibitor of cardiovascular problems, such as arteriosclerosis disease, high blood pressure, and capillary fragility [2].

Dietary fibers and phenolics are plant food constituents that play a beneficial role in human health, and use of these constituents as functional ingredients has gradually increased [7]. These constituents are usually studied separately due to differences in their metabolic pathways, physicochemical and biological properties, and chemical structures [8]. Recent studies, however, have reported that phenolics, as fiber copassengers, are bound to the fiber fraction and can be released along the gastrointestinal (GI) tract $[9,10]$. In particular, cereal dietary fibers with phenolics may play a role in antioxidant protection at the intestinal environmental level. In the GI tract, free phenolics are generally released from soluble dietary fibers by the activities of microbial and intestinal enzymes, such as esterases, and then absorbed through the intestine. Such a continuous absorption of phenolics can explain that the high consumption of whole grain can reduce the risk for developing diabetes, cancer, and cardiovascular diseases [9-11].

Flavonoids are well-known polyphenolic compounds consisting of a benzo- $\gamma$-pyrone structure and are commonly found in plant species. They are derived from the phenylpropanoid pathway [12]. These phenolic compounds are usually distributed in plant parts, including roots, stems, leafs, flowers, and fruits, herbs, vegetables, and nuts. These secondary metabolites are well-known components of food sources used in the daily human diet [13]. They exhibit various health benefits such as anti-inflammatory [14], antitumor, anti-human immunodeficiency virus [15], anti-tuberculosis [16], and anti-diabetic activities [17].

The accumulation of secondary metabolites is activated by abiotic stresses, signal molecules, or elicitors in various plants [18]. In particular, the production of secondary metabolites can be promoted by the elicitations by chitosan, salicylic acid, and jasmonic acid and by the ultraviolet-A/B radiation [19]. Chitosan elicitation leads to an increase in the production of phenylpropanoids. In chitosan-elicitated cells of Cocos nucifera (coconut), the production of phenolic compounds was enhanced in the cell suspension cultures [20]. Likewise, salicylic acid (2-hydroxybenzoic acid) from intact grape berries and jasmonic acid from the cells of Hypericum perforatum L. (St. John's wort) led to an increase in the total phenolic content. In particular, a rapid increase in the concentration of phenolic compounds was observed in JA-elicited cells compared to the control cells after 4 days of jasmonic acid (JA) elicitation [21]. An irradiation treatment with ultraviolet-A (UV-A) activated phenylalanine ammonia lyase (PAL), a key enzyme in the phenylpropanoid biosynthetic pathway, in tomato seedlings in addition to anthocyanin production in hypocotyls and fruit [22]. Furthermore, increase in hypericin and hyperforin accumulation was observed in H. perforatum exposed to ultraviolet-B (UV-B) radiation [23].

To our knowledge, no previous reports have documented the influence of chitosan, salicylic acid, and jasmonic acid on the accumulation of flavonoids in germinated buckwheat. Thus, the current study aimed to elucidate the effect of chitosan, salicylic acid, and jasmonic acid on the production of phenolic compounds in germinated buckwheat.

\section{Materials and Methods}

\subsection{Plant Materials}

Seeds of common buckwheat were obtained from Jeju Buckwheat Farmers Association Corp. (Je-ju do, Korea). Two hundred seeds (approximately $4 \mathrm{~g}$ ) were placed on filter paper (Whatman, 150-mm diameter) in a Petri dish (AccuResearch Korea, Seoul, South Korea, $150 \mathrm{~mm}$ diameter) and then treated with $200 \mathrm{~mL}$ of salicylic acid at concentrations of 50,100, and $150 \mathrm{mg} / \mathrm{L}$, jasmonic acid at concentrations of 50,100, and $150 \mu \mathrm{M}$, and chitosan at concentrations of $0.01,0.1$, and $0.5 \%$ (Figure 1 ). After incubation under a dark condition at $25^{\circ} \mathrm{C}$ for $72 \mathrm{~h}$, the germinated buckwheat seeds were harvested and frozen in liquid nitrogen $\left(-196^{\circ} \mathrm{C}\right)$. Individual samples were lyophilized and finely ground for further analysis. All samples were prepared in triplicate. 


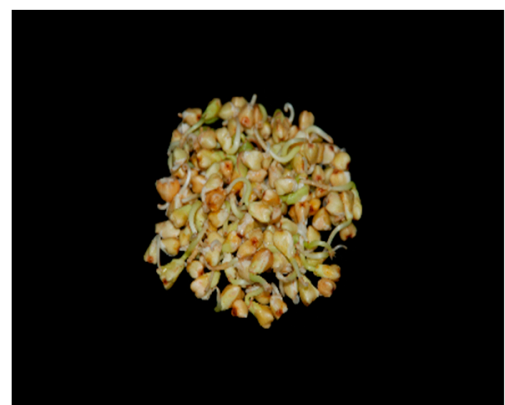

(a)

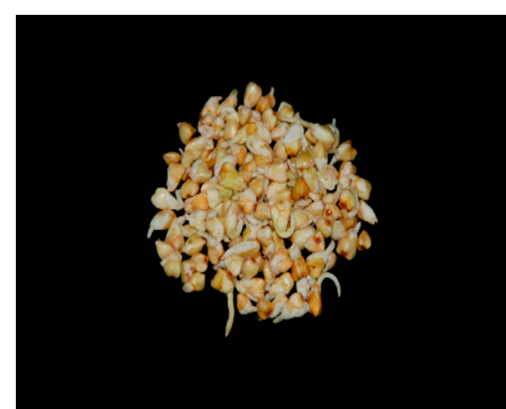

(b)

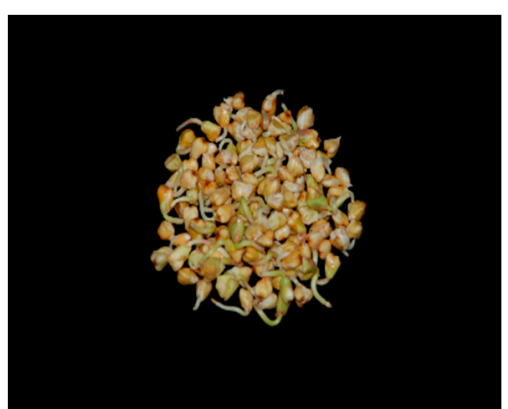

(c)

Figure 1. Buckwheat germinated for $72 \mathrm{~h}$. (a) Control; (b) germinated buckwheat treated with $150 \mu \mathrm{M}$ jasmonic acid; (c) germinated buckwheat treated with $0.1 \%$ chitosan.

\subsection{Extraction and High-Performance Liquid Chromatography Analysis of Phenolics}

The extraction and high-performance liquid chromatography (HPLC) analysis of phenolics in germinated buckwheat were performed according to the slightly modified method described by Park et al. [1]. For the extraction of phenolic compounds, $0.2 \mathrm{~g}$ of individual sample was soaked in $2 \mathrm{~mL}$ of aqueous methanol $(80 \% v / v)$ and vortexed for $30 \mathrm{~s}$. After sonication in a water bath at $37^{\circ} \mathrm{C}$ for $60 \mathrm{~min}$, the sample was centrifuged at $16,000 \times g$ for $15 \mathrm{~min}$, and the first supernatant was obtained. Additionally, the entire procedure was carried out twice. The collected supernatants were evaporated and then resuspended in $2 \mathrm{~mL}$ of methanol. The extracts were passed thorough a $0.45 \mu \mathrm{m}$ syringe filter into an HPLC vial. The analytical equipment and conditions for the HPLC analysis were performed as described by Park et al. [1]. The phenolic compounds were identified based on the retention time and spike test, followed by a calculation using respective calibration curves. The linear equations were $y=7.5252 x-37.3870\left(R^{2}=0.9997\right.$, recovery value $\left.=102.81 \pm 5.32 \%\right)$ for benzoic acid, $y=39.9829 x-65.7075\left(R^{2}=0.9999\right.$, recovery value $\left.=102.14 \pm 3.67 \%\right)$ for caffeic acid, $y=7.8897 x-$ $40.2424\left(R^{2}=0.9999\right.$, recovery value $\left.=104.09 \pm 11.25 \%\right)$ for catechin, $y=8.5989 x-8.3356\left(R^{2}=0.9999\right.$, recovery value $=100.28 \pm 0.80 \%)$ for epi-catechin, $y=32.8959 x-26.1737\left(R^{2}=0.9999\right.$, recovery value $=96.57 \pm 2.51 \%)$ for gallic acid, and $y=8.0971 x-105.5466\left(R^{2}=0.9995\right.$, recovery value $=104.61 \pm$ $11.17 \%$ ) for rutin. The chemical structures of the compounds are shown in Figure S1. The external standards were purchased from Sigma-Aldrich Co., Ltd. (St. Louis, MO, USA). The results were presented as microgram per milligram dry weight $(\mu \mathrm{g} / \mathrm{mg}(\mathrm{dw}))$ with means \pm standard deviation of triplicate experiments.

\subsection{Statistical Analysis}

Analysis of variance (ANOVA) test evaluates the statistical data and Duncan's multiple range test (DMRT) at $p<0.05$ were carried out using the SAS software (version 9.4, 2013; SAS Institute, Inc., Cary, NC, USA).

\section{Results}

\subsection{Effects of Elicitor Treatments on Germinated Buckwheat}

Table 1 shows the effect of elicitors used during germination on the accumulation of phenolic compounds in buckwheat sprouts. Six phenolic compounds (caffeic acid, catechine, chlorogenic acid, (-)-epicatechine, gallic acid, and rutin) and one organic acid (benzoic acid) were detected in germinated buckwheat. Even though benzoic acid does not belong to phenolic compound, the total phenolic compound of all samples were described, including benzoic acid. The treatment with $0.1 \%$ chitosan increased the total phenolic content compared with the control and the 0.01 and $0.5 \%$ chitosan treatments $(p<0.05)$. In particular, the total phenolics of the germinated buckwheat treated with $0.1 \%$ chitosan were approximately 1.23 times higher than the control buckwheat samples (Table 1 ). 
In addition, the concentration of gallic acid, catechin, chlorogenic acid, and (-)-epicatechin in the germinated buckwheat treated with $0.1 \%$ chitosan were approximately $15.86,1.72,1.64$, and 2.17 times higher than those of the control.

The six phenolic compounds were also detected by HPLC in buckwheat treated by JA. The germinated buckwheat treated with JA at the specific concentrations of 50, 100, and $150 \mu \mathrm{M}$ increased the accumulation of total phenolic compounds. The germinated buckwheat grown in $150 \mu \mathrm{M}$ of JA showed the highest amount of total phenolics which was approximately 2.47 times higher than that of control. Particularly, the accumulation of gallic acid, rutin, catechin, chlorogenic acid, and (-)-epicatechin were approximately 2.00, 2.38, 1.76, 2.81, and 7.95 times higher in JA-treated buckwheat than in the control buckwheat samples (Table 1). However, SA treatment did not influence the production of phenolic compounds.

\subsection{Time-Course Effects of $0.1 \%$ Chitosan Treatment on Phenolic Compounds of Germinated Buckwheat}

Owing to the highest accumulation of total phenolics after $0.1 \%$ chitosan treatment, the accumulation of phenolic compounds in $0.1 \%$ chitosan-treated buckwheat was studied throughout the germination process $(6,12,24,48$, and $72 \mathrm{~h})$. As a result, the concentration of total phenolic compounds increased after $72 \mathrm{~h}$, and it was the highest accumulation of phenolics compared with all the control groups $(6,12,24,48$, and $72 \mathrm{~h})$. In particular, at $72 \mathrm{~h}$, the amounts of gallic acid, chlorogenic acid, (-)-epicatechin, and rutin were higher in the chitosan-treated buckwheat than in the buckwheat under control (Table 2). However, the fresh and dry weight $(\mathrm{g})$ of germinated buckwheats after $72 \mathrm{~h}$ were not significantly different compared with those of the control (Table S1).

\subsection{Time-Course Effects of $150 \mu M$ Jasmonic Acid Treatment on Phenolic Compounds of Germinated Buckwheat}

The time course experiments at 6, 12, 24, 48, and $72 \mathrm{~h}$ were also conducted in buckwheat germinated in the presence of $150 \mu \mathrm{M}$ jasmonic acid. As a result, the accumulation of total phenolic compounds increased after $72 \mathrm{~h}$. Particularly, the germinated buckwheat treated with $150 \mu \mathrm{M}$ jasmonic acid for $72 \mathrm{~h}$ showed the highest concentration of total phenolics compared with the control buckwheat samples. Likewise, gallic acid, chlorogenic acid, (-)-epicatechin, and rutin showed the highest levels in the jasmonic acid-treated germinated buckwheat as compared with the control and other treatments (Table 2). However, the fresh and dry weight (g) of germinated buckwheats after $72 \mathrm{~h}$ were not significantly different compared with those of the control (Table S1). 
Table 1. The effect of elicitors (chitosan, jasmonic acid (JA), salicylic acid (SA)) on the accumulation of phenolic compounds ( $\mu \mathrm{g} / \mathrm{g}(\mathrm{dw})$ ).

\begin{tabular}{|c|c|c|c|c|c|c|c|c|}
\hline & Benzoic Acid & Caffeic Acid & Catechin & Chlorogenic Acid & (-)-Epicatechin & Gallic Acid & Rutin & Total \\
\hline Control & $74.48 \pm 5.27^{\mathrm{abc}, 1}$ & $77.99 \pm 1.54^{\mathrm{cd}}$ & $56.18 \pm 2.37^{c}$ & $58.92 \pm 1.52^{d}$ & $44.44 \pm 8.55^{\mathrm{d}}$ & $6.09 \pm 0.19^{c}$ & $424.42 \pm 0.96^{\text {cde }}$ & $736.43 \pm 11.35^{\mathrm{e}}$ \\
\hline Chitosan $0.01 \%$ & $71.34 \pm 4.48^{\mathrm{bc}}$ & $82.52 \pm 8.84^{\mathrm{cd}}$ & $64.32 \pm 6.63^{c}$ & $81.62 \pm 11.69 \mathrm{bc}$ & $48.79 \pm 27.38^{d}$ & $6.27 \pm 0.44^{c}$ & $399.7 \pm 53.28$ def & $754.55 \pm 105.14^{\mathrm{e}}$ \\
\hline Chitosan $0.1 \%$ & $58.17 \pm 4.38^{\mathrm{d}}$ & $81.25 \pm 4.12^{\mathrm{cd}}$ & $96.59 \pm 8.06^{b}$ & $99.66 \pm 2.91^{b}$ & $98.51 \pm 17.90^{\mathrm{c}}$ & $9.19 \pm 1.91^{b}$ & $465.76 \pm 50.35^{\mathrm{cd}}$ & $909.12 \pm 76.28^{d}$ \\
\hline Chitosan $0.5 \%$ & $68.56 \pm 9.03 \mathrm{bcd}$ & $70.27 \pm 5.52^{d}$ & $66.34 \pm 9.52^{c}$ & $66.56 \pm 3.16^{\mathrm{cd}}$ & $24.96 \pm 18.03^{d}$ & $5.61 \pm 0.45^{c}$ & $341.12 \pm 35.09^{f}$ & $643.43 \pm 26.63^{\mathrm{e}}$ \\
\hline JA $50 \mu \mathrm{M}$ & $59.49 \pm 2.84^{\mathrm{d}}$ & $96.61 \pm 7.19 b c$ & $104.71 \pm 10.35^{b}$ & $150.7 \pm 23.68^{a}$ & $297.41 \pm 53.66^{b}$ & $10.8 \pm 2.00^{a b}$ & $494.99 \pm 65.45^{c}$ & $1214.71 \pm 153.05^{c}$ \\
\hline JA $100 \mu \mathrm{M}$ & $58.06 \pm 6.47^{d}$ & $104.76 \pm 17.15^{\mathrm{ab}}$ & $136.12 \pm 32.75^{\mathrm{a}}$ & $155.34 \pm 8.87^{a}$ & $299.5 \pm 25.82^{b}$ & $10.5 \pm 1.68^{a b}$ & $764.39 \pm 39.19^{b}$ & $1528.66 \pm 108.41^{b}$ \\
\hline JA $150 \mu \mathrm{M}$ & $68.17 \pm 3.74^{\mathrm{cd}}$ & $115.63 \pm 11.79^{a}$ & $98.8 \pm 23.94^{b}$ & $165.33 \pm 22.43^{\mathrm{a}}$ & $353.28 \pm 13.17^{a}$ & $12.17 \pm 0.85^{\mathrm{a}}$ & $1011.3 \pm 3.11^{\mathrm{a}}$ & $1824.69 \pm 72.80^{a}$ \\
\hline SA $50 \mathrm{mg} / \mathrm{L}$ & $79.48 \pm 10.83 \mathrm{ab}$ & $65.19 \pm 19.09^{d}$ & $61.94 \pm 4.92^{\mathrm{c}}$ & $56.08 \pm 5.78^{d}$ & $31.55 \pm 7.38^{\mathrm{d}}$ & $6.83 \pm 0.28^{c}$ & $375.63 \pm 72.65^{\text {ef }}$ & $676.7 \pm 111.09 \mathrm{e}$ \\
\hline $\mathrm{SA} 100 \mathrm{mg} / \mathrm{L}$ & $76.12 \pm 2.94 \mathrm{abc}$ & $73.11 \pm 6.12^{d}$ & $58.92 \pm 1.2^{c}$ & $58.98 \pm 1.86^{\mathrm{d}}$ & $37.62 \pm 4.64^{d}$ & $6.24 \pm 1.14^{c}$ & $420.9 \pm 32.14$ cdef & $731.89 \pm 42.04 \mathrm{e}^{\mathrm{e}}$ \\
\hline SA $150 \mathrm{mg} / \mathrm{L}$ & $84.75 \pm 1.76^{a}$ & $78.63 \pm 0.51^{\mathrm{cd}}$ & $59.4 \pm 1.17^{c}$ & $62.21 \pm 1.71^{\mathrm{cd}}$ & $44.93 \pm 2.32^{\mathrm{d}}$ & $7.24 \pm 0.13^{c}$ & $456.62 \pm 6.31^{\text {cde }}$ & $793.79 \pm 7.02 \mathrm{de}$ \\
\hline
\end{tabular}

${ }^{1}$ Means with different letters in the same column differ significantly $(p<0.05$, Duncan multiple range test (DMRT)).

Table 2. High-performance liquid chromatography (HPLC) analysis of total phenolic compounds in the germinated buckwheat under $150 \mu \mathrm{M}$ jasmonic acid and $0.1 \%$

chitosan time-course treatment $(\mu \mathrm{g} / \mathrm{g}(\mathrm{dw}))$.

\begin{tabular}{|c|c|c|c|c|c|c|c|c|}
\hline & Benzoic Acid & Caffeic Acid & Catechin & Chlorogenic Acid & (-)-Epicatechin & Gallic Acid & Rutin & Total \\
\hline Control $6 \mathrm{~h}$ & $81.96 \pm 4.91 \mathrm{abc}, 1$ & $74.93 \pm 2.37$ def & $57.21 \pm 2.11^{\mathrm{c}}$ & $55.72 \pm 2.24^{c}$ & $43.13 \pm 5.89 \mathrm{de}$ & $6.78 \pm 0.86^{\text {defgh }}$ & $371.84 \pm 81.94^{d}$ & $691.57 \pm 97.47^{\mathrm{de}}$ \\
\hline Control $12 \mathrm{~h}$ & $83.82 \pm 3.10^{\mathrm{ab}}$ & $74.29 \pm 2.57 \mathrm{def}$ & $66.30 \pm 3.85^{c}$ & $59.91 \pm 3.24^{c}$ & $39.60 \pm 1.00$ de & $8.03 \pm 0.45^{\mathrm{cd}}$ & $428.66 \pm 6.33^{\mathrm{cd}}$ & $760.60 \pm 6.96 \mathrm{de}$ \\
\hline Control $24 \mathrm{~h}$ & $83.27 \pm 1.96^{\mathrm{ab}}$ & $76.44 \pm 3.48^{\mathrm{cdef}}$ & $65.97 \pm 2.04^{c}$ & $61.52 \pm 0.97 c$ & $34.10 \pm 1.41 \mathrm{de}$ & $6.98 \pm 0.36^{\text {defgh }}$ & $418.00 \pm 16.50^{\mathrm{cd}}$ & $746.28 \pm 23.56^{d e}$ \\
\hline Control $48 \mathrm{~h}$ & $71.64 \pm 9.63 \mathrm{de}$ & $84.56 \pm 8.24^{b c}$ & $99.05 \pm 15.37^{b}$ & $105.81 \pm 32.67^{b}$ & $135.74 \pm 95.97^{c}$ & $7.91 \pm 1.56^{\text {cde }}$ & $291.20 \pm 100.31^{\mathrm{e}}$ & $795.91 \pm 95.38^{\mathrm{cc}}$ \\
\hline Control $72 \mathrm{~h}$ & $74.48 \pm 5.27$ cde & $77.99 \pm 1.54^{\text {cde }}$ & $56.18 \pm 2.37^{c}$ & $58.92 \pm 1.52^{c}$ & $44.44 \pm 8.55$ de & $6.09 \pm 0.19^{h}$ & $424.42 \pm 0.96^{\mathrm{cd}}$ & $736.43 \pm 11.35^{d e}$ \\
\hline Chitosan $6 \mathrm{~h}$ & $80.78 \pm 2.42^{\mathrm{abc}}$ & $69.16 \pm 1.78$ ef & $52.53 \pm 0.87^{c}$ & $57.24 \pm 1.58^{c}$ & $23.58 \pm 2.47^{\mathrm{e}}$ & $7.83 \pm 0.63$ cde & $346.41 \pm 12.92$ de & $637.53 \pm 14.44 \mathrm{e}$ \\
\hline Chitosan $12 \mathrm{~h}$ & $80.59 \pm 3.57 \mathrm{abc}$ & $67.95 \pm 1.60^{\mathrm{f}}$ & $54.11 \pm 3.32^{c}$ & $55.47 \pm 0.79^{c}$ & $20.00 \pm 3.43^{e}$ & $6.33 \pm 0.22 \mathrm{fgh}$ & $346.22 \pm 23.57$ de & $630.67 \pm 34.24^{\mathrm{e}}$ \\
\hline Chitosan $24 \mathrm{~h}$ & $80.64 \pm 0.57 \mathrm{abc}$ & $67.89 \pm 2.22^{f}$ & $57.30 \pm 0.63^{c}$ & $55.36 \pm 0.04^{c}$ & $21.26 \pm 1.66^{\mathrm{e}}$ & $6.45 \pm 0.25^{\text {efgh }}$ & $367.70 \pm 26.01$ de & $656.61 \pm 25.54 \mathrm{de}$ \\
\hline Chitosan 48 h & $78.79 \pm 0.43 \mathrm{abcd}$ & $73.47 \pm 1.71$ def & $70.25 \pm 9.12^{c}$ & $72.28 \pm 9.49^{c}$ & $55.14 \pm 28.34 \mathrm{de}$ & $6.14 \pm 0.29 \mathrm{gh}$ & $408.89 \pm 15.52^{\mathrm{cd}}$ & $764.96 \pm 63.46^{\mathrm{de}}$ \\
\hline Chitosan $72 \mathrm{~h}$ & $58.17 \pm 4.38^{\mathrm{f}}$ & $81.25 \pm 4.12^{\mathrm{cd}}$ & $96.59 \pm 8.06^{b}$ & $99.66 \pm 2.91^{b}$ & $98.51 \pm 17.90^{\mathrm{cd}}$ & $9.19 \pm 1.91 b c$ & $465.76 \pm 50.35^{c}$ & $909.12 \pm 76.28^{c}$ \\
\hline Jasmonic acid $6 \mathrm{~h}$ & $77.14 \pm 2.18^{a b c d}$ & $76.42 \pm 4.33^{\mathrm{cdef}}$ & $55.06 \pm 0.83^{c}$ & $60.78 \pm 0.41^{\mathrm{c}}$ & $39.81 \pm 6.70$ de & $7.58 \pm 0.09$ defg & $408.23 \pm 16.91^{\mathrm{cd}}$ & $725.03 \pm 29.48^{\mathrm{d} e}$ \\
\hline Jasmonic acid $12 \mathrm{~h}$ & $76.13 \pm 2.83^{b c d}$ & $74.11 \pm 1.01$ def & $56.20 \pm 0.54^{c}$ & $69.99 \pm 1.64^{c}$ & $40.19 \pm 0.48^{\mathrm{de}}$ & $8.04 \pm 0.26^{\mathrm{cd}}$ & $418.48 \pm 18.94^{\mathrm{cd}}$ & $743.15 \pm 20.99 \mathrm{~d}$ \\
\hline Jasmonic acid $24 \mathrm{~h}$ & $74.63 \pm 2.15^{\mathrm{cde}}$ & $80.45 \pm 2.57^{\mathrm{cd}}$ & $62.54 \pm 2.92^{c}$ & $70.34 \pm 0.60^{c}$ & $38.88 \pm 6.56^{\text {de }}$ & $7.69 \pm 0.42$ def & $395.77 \pm 18.89^{\mathrm{cd}}$ & $730.30 \pm 22.81^{d e}$ \\
\hline Jasmonic acid $48 \mathrm{~h}$ & $84.85 \pm 3.43^{a}$ & $91.14 \pm 5.84^{b}$ & $165.89 \pm 51.97^{\mathrm{a}}$ & $109.62 \pm 20.75^{b}$ & $202.38 \pm 89.88^{b}$ & $9.79 \pm 0.35^{b}$ & $541.76 \pm 68.57^{b}$ & $1205.4 \pm 240.79^{b}$ \\
\hline Jasmonic acid $72 \mathrm{~h}$ & $68.17 \pm 3.74 \mathrm{e}^{\mathrm{e}}$ & $115.63 \pm 11.79^{a}$ & $98.80 \pm 23.94^{b}$ & $165.33 \pm 22.43^{a}$ & $353.8 \pm 13.17^{a}$ & $12.17 \pm 0.85^{a}$ & $1011.30 \pm 3.11^{\mathrm{a}}$ & $1824.6 \pm 72.80^{a}$ \\
\hline
\end{tabular}

${ }^{1}$ Means with different letters in the same column differ significantly $(p<0.05$, Duncan multiple range test (DMRT)). 


\section{Discussion}

In this study, six phenolic compounds (gallic acid, catechin, chlorogenic acid, caffeic acid, (-)-epicatachin, and rutin) and one organic acid (benzoic acid) were detected in germinated buckwheat. These results are consistent with previous studies reporting the identification of gallic acid, chlorogenic acid, catechin, caffeic acid, (-)-epicatechin, and rutin in common buckwheat sprouts [24] and flours [25]. Furthermore, the presence of caffeic and benzoic acids was recorded in buckwheat honeys and four different phenolics, including catechin, chlorogenic acid, epicatechin, and rutin, were identified in different parts, such as stem, leaf, flower, and root, of the Korean common buckwheat cultivars [26].

This time course analysis revealed that chitosan and JA gradually enhanced the production of phenolic compounds in the germinated buckwheat. We carefully suggested that it might be due to increased gene expression levels of phenylpropanoid-related genes by the chitosan and JA elicitation since our previous studies reported that the methyl jasmonate increased gene expression levels of phenlypropanoid-related genes and enhanced the accumulation of phenolic compounds in radish sprouts [27] and in Agastache rugosa Kuntze [28], respectively. Furthermore, Chen et al. (2009) reported the increased expression of phenylpropanoid and flavonoid biosynthesis genes and in soybean sprouts treated with chitosan [29].

Among the detected phenolics in the germinated buckwheat at $72 \mathrm{~h}$ after the treatment of $150 \mu \mathrm{M}$ JA and $0.1 \%$ chitosan, the concentration of rutin, (-)-epicatechin, and chlorogenic acid significantly increased. Rutin, the most abundant phenolic compound in the elicited germinated buckwheat, is used as a health supplement and has applications in food industries due to its biological activities, including anti-oxidant, anti-inflammatory, and anti-diabetic activities [30]. Similarly, (-)-epicatechin, the second most abundant compound, has been introduced as a health supplement because it enhances fatigue resistance and oxidative capacity [31,32]. Chlorogenic acid, the third most abundant compound, has been mainly used in food processing and cosmetic industries since the compound possesses anti-carcinogenic [33], anti-inflammatory [34], and anti-oxidant functions [35]. The other identified compounds have been reported to have health-beneficial effect, such as anti-cancer and anti-oxidant effects [36-38].

Elicitation is considered one of the best strategies to stimulate secondary metabolites. The accumulation of secondary metabolites from either parts of parent or transformed plants is greatly dependent on the sources of their origin; however, it might be influenced by the treatments as well as environmental factors. Elicitors, when in contact with the cells of higher plants, trigger an increase in the production of pigments, flavones, phytoalexins, and other defense-related compounds [39-42]. This study revealed that treatment with elicitors chitosan or jasmonic acid can enhance the production of phenolic compounds in germinated buckwheat. This finding was consistent with previous studies of Park et al. (2017) [1] and Kim et al. (2011) [43], who reported the enhancement of phenolics in the sprouts of common buckwheat by treatment with indoleacetic acid and methyl jasmonic acid, respectively. Li et al. (2015) [44] reported the positive effect of the exogenous application of sucrose on the flavonoid contents of common buckwheat seedlings. Lim et al. (2012) [45] reported that the sodium chloride $(\mathrm{NaCl})$ treatment enhanced both phenylpropanoid and carotenoid production in buckwheat sprouts. In addition, elicitors could stimulate the biosynthesis of phenylpropanoid compounds in tartary buckwheat (F. tataricum (L.) Gaertn.). Zhao et al. (2015) [46] reported an increase in flavonoid production in sprout cultures under treatment of polysaccharide elicitors. Sun et al. (2012) [47] reported that the treatment with salicylic acid resulted in an increase in rutin production in tartary buckwheat leaves. Li et al. (2017) [48] also described that exogenous ethephon application enhanced phenylpropanoid biosynthesis. Furthermore, Park et al. (2016) [49] reported that treatment with auxins improved anthocyanin production in the hairy root cultures of tartary buckwheat.

Chitosan and JA affect the phenlypropanoid biosynthesis in plants. Previous studies reported that chitosan increases the activity of key enzymes (phenylalanine ammonia-lyase (PAL) and tyrosine ammonia-lyase) of the phenylpropanoid pathway [50], and JA also increases PAL activity [51]. Furthermore, chitosan treatment enhanced the accumulation of free and bound phenolic acids in 
peanut seeds [52]. Mandal et al. (2016) [53] reported that chitosan increased the production of cell wall-bound phenolic compounds in Solanum Melongena. Moreover, methyl jasmonic acid could increase these phenolic compounds [53]. Additionally, Skrzypczak-Pietraszek et al. (2014) [54] reported that the production of free and bound phenolic acids increased by adding methyl jasmonic acid in shoot cultures of Exacum affine Balf. f. ex Regel. Therefore, we carefully suggest that JA and chitosan treatment enhance the production of free and bound phenolic compounds in plants.

\section{Conclusions}

This study confirmed that JA and chitosan play an important role in the production of phenolic compounds in germinated buckwheat. A total of six phenolics (gallic acid, catechin, chlorogenic acid, caffeic acid, (-)-epicatechin, and rutin) and one organic acid (benzoic acid) were detected in germinated buckwheat. JA and chitosan treatment enhanced the accumulation of phenolic compounds in the germinated buckwheat. Particularly, treatments with $150 \mu \mathrm{M} \mathrm{JA}$ were the most effective on the accumulation of phenolic compounds. According to the time-course analysis, a $72 \mathrm{~h}$ chitosan treatment enhanced the production of phenolics. Similarly, the germinated buckwheat treated for 48 and $72 \mathrm{~h}$ showed a higher accumulation of phenolic compounds than control buckwheat. Thus, these results might help build sturdy strategies for enhancing the production of phenolics in germinated buckwheat as a good nutritional source for human consumption.

Supplementary Materials: The following are available online at http://www.mdpi.com/2304-8158/8/5/153/s1. Figure S1: Chemical structures of the phenolic compounds and benzoic acid, Table S1: The effect of $0.1 \%$ chitosan and $150 \mu \mathrm{M}$ jasmonic acid on the growth of germinated buckwheats grown for $72 \mathrm{~h}$.

Author Contributions: S.Y.L. and S.U.P. designed the experiments and analyzed the data. C.H.P., H.J.Y., Y.E.P., S.W.C., and Y.S.C. performed the experiments and analyzed the data. C.H.P. and H.J.Y. wrote the manuscript. All authors read and approved the final manuscript.

Funding: This study was supported by research fund of Jeju Buckwheat Promotion Group.

Acknowledgments: We thank Jeju Buckwheat Farmers Association Corp. (Je-ju do, Korea) for providing seeds of common buckwheat used in this work.

Conflicts of Interest: The authors declare no conflict of interest.

\section{References}

1. Park, C.H.; Yeo, H.J.; Park, Y.J.; Morgan, A.; Valan Arasu, M.; Al-Dhabi, N.A.; Park, S.U. Influence of indole-3-acetic acid and gibberellic acid on phenylpropanoid accumulation in common buckwheat (Fagopyrum esculentum Moench) sprouts. Molecules 2017, 22, 374. [CrossRef]

2. Kreft, I.; Fabjan, N.; Germ, M. Rutin in buckwheat: Protection of plants and its importance for the production of functional food. Fagopyrum 2003, 20, 7-11.

3. Kim, C.D.; Lee, W.-K.; No, K.-O.; Park, S.-K.; Lee, M.-H.; Lim, S.R.; Roh, S.-S. Anti-allergic action of buckwheat (Fagopyrum esculentum Moench) grain extract. Int. Immunopharmacol. 2003, 3, 129-136. [CrossRef]

4. Potapovich, A.; Kostyuk, V. Comparative study of antioxidant properties and cytoprotective activity of flavonoids. Biochemistry (Moscow) 2003, 68, 514-519. [CrossRef]

5. Choi, J.-H.; Kim, D.-W.; Park, S.-E.; Lee, H.-J.; Kim, K.-M.; Kim, K.-J.; Kim, M.-K.; Kim, S.-J.; Kim, S. Anti-thrombotic effect of rutin isolated from Dendropanax morbifera Leveille. J. Biosci. Bioeng. 2015, 120, 181-186. [CrossRef]

6. Deschner, E.E.; Ruperto, J.; Wong, G.; Newmark, H.L. Quercetin and rutin as inhibitors of azoxymethanol-induced colonic neoplasia. Carcinogenesis 1991, 12, 1193-1196. [CrossRef] [PubMed]

7. Quirós-Sauceda, A.; Palafox-Carlos, H.; Sáyago-Ayerdi, S.; Ayala-Zavala, J.; Bello-Perez, L.A.; Alvarez-Parrilla, E.; De La Rosa, L.; Gonzalez-Cordova, A.; Gonzalez-Aguilar, G. Dietary fiber and phenolic compounds as functional ingredients: Interaction and possible effect after ingestion. Food Funct. 2014, 5 , 1063-1072. [CrossRef]

8. Saura-Calixto, F. Dietary fiber as a carrier of dietary antioxidants: An essential physiological function. J. Agric. Food Chem. 2010, 59, 43-49. [CrossRef] 
9. Vitaglione, P.; Napolitano, A.; Fogliano, V. Cereal dietary fibre: A natural functional ingredient to deliver phenolic compounds into the gut. Trends Food Sci. Technol. 2008, 19, 451-463. [CrossRef]

10. Fardet, A. New concepts and paradigms for the protective effects of plant-based food components in relation to food complexity. In Vegetarian and Plant-Based Diets in Health and Disease Prevention; Mariotti, F., Ed.; Elsevier: New York, NY, USA, 2017; pp. 293-314. ISBN 9780128039687.

11. Kris-Etherton, P.M.; Hecker, K.D.; Bonanome, A.; Coval, S.M.; Binkoski, A.E.; Hilpert, K.F.; Griel, A.E.; Etherton, T.D. Bioactive compounds in foods: Their role in the prevention of cardiovascular disease and cancer. Am. J. Med. 2002, 113, 71-88. [CrossRef]

12. Kumar, S.; Pandey, A.K. Chemistry and biological activities of flavonoids: An overview. Sci. World J. 2013, 2013, 162750. [CrossRef]

13. Middleton, E.; Kandaswami, C.; Theoharides, T.C. The effects of plant flavonoids on mammalian cells: Implications for inflammation, heart disease, and cancer. Pharmacol. Rev. 2000, 52, 673-751. [PubMed]

14. Aboutabl, E.; Hashem, F.A.; Sleem, A.; Maamoon, A. Flavonoids, anti-inflammatory activity and cytotoxicity of Macfadyena unguis-cati L. Afr. J. Tradit. Complement. Altern. Med. 2008, 5, 18-26. [CrossRef]

15. Wang, H.-K.; Xia, Y.; Yang, Z.-Y.; Natschke, S.L.M.; Lee, K.-H. Recent advances in the discovery and development of flavonoids and their analogues as antitumor and anti-HIV agents. In Flavonoids in the Living System; Springer: Boston, MA, USA, 1998; Volume 439, pp. 191-225.

16. Lin, Y.-M.; Zhou, Y.; Flavin, M.T.; Zhou, L.-M.; Nie, W.; Chen, F.-C. Chalcones and flavonoids as anti-tuberculosis agents. Biorg. Med. Chem. 2002, 10, 2795-2802. [CrossRef]

17. Babu, P.V.A.; Liu, D.; Gilbert, E.R. Recent advances in understanding the anti-diabetic actions of dietary flavonoids. J. Nutr. Biochem. 2013, 24, 1777-1789. [CrossRef] [PubMed]

18. Zhao, J.; Davis, L.C.; Verpoorte, R. Elicitor signal transduction leading to production of plant secondary metabolites. Biotechnol. Adv. 2005, 23, 283-333. [CrossRef]

19. Ramachandra, R.S.; Ravishankar, G.A. Plant cell cultures: Chemical factories of secondary metanolites. Biotechnol. Adv. 2002, 20, 101-153. [CrossRef]

20. Chakraborty, M.; Karun, A.; Mitra, A. Accumulation of phenylpropanoid derivatives in chitosan-induced cell suspension culture of Cocos nucifera. J. Plant Physiol. 2009, 166, 63-71. [CrossRef]

21. Gadzovska, S.; Maury, S.; Delaunay, A.; Spasenoski, M.; Joseph, C.; Hagege, D. Jasmonic acid elicitation of Hypericum perforatum L. cell suspensions and effects on the production of phenylpropanoids and naphtodianthrones. Plant Cell Tiss. Org. Cult. 2007, 89, 1-13. [CrossRef]

22. Guo, J.; Wang, M.-H. Ultraviolet A-specific induction of anthocyanin biosynthesis and PAL expression in tomato (Solanum lycopersicum L.). Plant. Growth Regul. 2010, 62, 1-8. [CrossRef]

23. Brechner, M.L.; Albright, L.D.; Weston, L.A. Effects of UV-B on secondary metabolites of St. john's wort (Hypericum perforatum L.) grown in controlled environments. Photochem. Photobiol. 2011, 87, 680-684. [CrossRef]

24. Li, X.; Park, N.I.; Xu, H.; Woo, S.-H.; Park, C.H.; Park, S.U. Differential expression of flavonoid biosynthesis genes and accumulation of phenolic compounds in common buckwheat (Fagopyrum esculentum). J. Agric. Food Chem. 2010, 58, 12176-12181. [CrossRef]

25. Inglett, G.E.; Chen, D.; Berhow, M.; Lee, S. Antioxidant activity of commercial buckwheat flours and their free and bound phenolic compositions. Food Chem. 2011, 125, 923-929. [CrossRef]

26. Uddin, M.R.; Li, X.; Park, W.T.; Kim, Y.B.; Kim, S.J.; Kim, Y.S.; Lee, M.Y.; Park, C.H.; Park, S.U. Phenolic compound content in different organs of Korean common buckwheat cultivars. Asian J. Chem. 2013, 25, 424-426. [CrossRef]

27. Chen, H.; Seguin, P.; Archambault, A.; Constan, L.; Jabaji, S. Gene expression and isoflavone concentrations in soybean sprouts treated with chitosan. Crop Sci. 2009, 49, 224-236. [CrossRef]

28. Kim, Y.B.; Kim, J.K.; Uddin, M.R.; Xu, H.; Park, W.T.; Tuan, P.A.; Li, X.; Chung, E.; Lee, J.-H.; Park, S.U. Metabolomics analysis and biosynthesis of rosmarinic acid in Agastache rugosa Kuntze treated with methyl jasmonate. PLOS ONE 2013, 8, e64199. [CrossRef]

29. Park, W.T.; Kim, Y.B.; Seo, J.M.; Kim, S.-J.; Chung, E.; Lee, J.-H.; Park, S.U. Accumulation of anthocyanin and associated gene expression in radish sprouts exposed to light and methyl jasmonate. J. Agric. Food Chem. 2013, 61, 4127-4132. [CrossRef] [PubMed]

30. Chua, L.S. A review on plant-based rutin extraction methods and its pharmacological activities. J. Ethnopharmacol. 2013, 150, 805-817. [CrossRef] 
31. Wang, H.; Cao, Z. Anti-inflammatory effects of (-)-epicatechin in lipopolysaccharide-stimulated raw 264.7 macrophages. Trop. J. Pharm. Res. 2014, 13, 1415-1419. [CrossRef]

32. Nogueira, L.; Ramirez-Sanchez, I.; Perkins, G.A.; Murphy, A.; Taub, P.R.; Ceballos, G.; Villarreal, F.J.; Hogan, M.C.; Malek, M.H. (-)-Epicatechin enhances fatigue resistance and oxidative capacity in mouse muscle. J. Physiol. 2011, 589, 4615-4631. [CrossRef]

33. Azuma, K.; Ippoushi, K.; Nakayama, M.; Ito, H.; Higashio, H.; Terao, J. Absorption of chlorogenic acid and caffeic acid in rats after oral administration. J. Agric. Food Chem. 2000, 48, 5496-5500. [CrossRef] [PubMed]

34. Jiang, F.; Dusting, G.J. Natural phenolic compounds as cardiovascular therapeutics: Potential role of their antiinflammatory effects. Curr. Vasc. Pahrmacol. 2003, 1, 135-156. [CrossRef]

35. Xiang, Z.; Ning, Z. Scavenging and antioxidant properties of compound derived from chlorogenic acid in South-China honeysuckle. LWT-Food Sci. Technol. 2008, 41, 1189-1203. [CrossRef]

36. Kaur, M.; Velmurugan, B.; Rajamanickam, S.; Agarwal, R.; Agarwal, C. Gallic acid, an active constituent of grape seed extract, exhibits anti-proliferative, pro-apoptotic and anti-tumorigenic effects against prostate carcinoma xenograft growth in nude mice. Pharm. Res. 2009, 26, 2133-2140. [CrossRef] [PubMed]

37. Higdon, J.V.; Frei, B. Tea catechins and polyphenols: Health effects, metabolism, and antioxidant functions. Crit. Rev. Food Sci. Nutr. 2003, 43, 89-143. [CrossRef]

38. Chen, J.H.; Ho, C.-T. Antioxidant activities of caffeic acid and its related hydroxycinnamic acid compounds. J. Agric. Food Chem. 1997, 45, 2374-2378. [CrossRef]

39. Flores, H.E.; Curtis, W.R. Approaches to Understanding and Manipulating the Biosynthetic Potential of Plant Roots. Ann. N. Y. Acad. Sci. 1992, 665, 188-209. [CrossRef] [PubMed]

40. Sim, S.J.; Chang, H.N.; Liu, J.R.; Jung, K.H. Production and secretion of indole alkaloids in hairy root cultures of Catharanthus roseus: Effects of in situ adsorption, fungal elicitation and permeabilization. J. Ferment. Bioeng. 1994, 78, 229-234.

41. Bhagyalakshmi, N.; Bopanna, K. Elicitation and immobilization of cell cultures for enhanced synthesis of pharmaceutical compounds. In Role of Biotechnology in Medicinal and Aromatic Plants; Ukaaz Publications: Hyderabad, India, 1998; Volume 1, pp. 305-325.

42. Singh, G. Elicitation-Manipulating and enhancing secondary metabolite production. In Plant Cell and Tissue Culture for the Production of Food Ingredients; Springer: New York, NY, USA, 1999; pp. 101-111.

43. Kim, H.-J.; Park, K.-J.; Lim, J.-H. Metabolomic analysis of phenolic compounds in buckwheat (Fagopyrum esculentum M.) sprouts treated with methyl jasmonate. J. Agric. Food Chem. 2011, 59, 5707-5713. [CrossRef]

44. Li, X.; Park, N.I.; Park, C.H.; Kim, S.G.; Lee, S.Y.; Park, S.U. Influence of Sucrose on Rutin Content and Flavonoid Biosynthetic Gene Expression in Seedlings of Common Buckwheat (Fagopyrum esculentum Moench). Plant Omics 2011, 4, 215-219.

45. Lim, J.-H.; Park, K.-J.; Kim, B.-K.; Jeong, J.-W.; Kim, H.-J. Effect of salinity stress on phenolic compounds and carotenoids in buckwheat (Fagopyrum esculentum M.) sprout. Food Chem. 2012, 135, 1065-1070. [CrossRef]

46. Zhao, J.; Zou, L.; Zhong, L.; Peng, L.; Ying, P.; Tan, M.; Zhao, G. Effects of polysaccharide elicitors from endophytic Bionectria pityrodes Fat6 on the growth and flavonoid production in tartary buckwheat sprout cultures. Cereal Res. Commun. 2015, 43, 661-671. [CrossRef]

47. Sun, Z.; Hou, S.; Yang, W.; Han, Y. Exogenous application of salicylic acid enhanced the rutin accumulation and influenced the expression patterns of rutin biosynthesis related genes in Fagopyrum tartaricum Gaertn leaves. Plant Growth Regul. 2012, 68, 9-15. [CrossRef]

48. Li, X.; Thwe, A.A.; Park, C.H.; Kim, S.J.; Arasu, M.V.; Abdullah Al-Dhabi, N.; Lee, S.Y.; Park, S.U. Ethephon-induced phenylpropanoid accumulation and related gene expression in tartary buckwheat (Fagopyrum tataricum (L.) Gaertn.) hairy root. Biotechnol. Biotechnol. Equip. 2017, 31, 304-311. [CrossRef]

49. Park, C.H.; Thew, A.A.; Kim, S.J.; Park, J.S.; Arasu, M.V.; Abdullah Al-Dhabi, N.; Park, N.I.; Park, S.U. Effect of Auxins on Anthocyanin Accumulation in Hairy Root Cultures of Tartary Buckwheat Cultivar Hokkai T10. Nat. Prod. Commun. 2016, 11, 1283-1286. [CrossRef] [PubMed]

50. Khan, W.; Prithiviraj, B.; Smith, D.L. Chitosan and chitin oligomers increase phenylalanine ammonia-lyase and tyrosine ammonia-lyase activities in soybean leaves. J. Plant Physiol. 2003, 160, 859-863. [CrossRef]

51. Wang, Q.Y.; Chen, X.L.; Chai, X.F.; Xue, D.Q.; Zheng, W.; Shi, Y.Y.; Wang, A.X. The Involvement of Jasmonic Acid, Ethylene and Salicylic Acid in the Signaling Pathway of Clonostachys rosea-Induced Resistance to Gray Mold Disease in Tomato. Phytopathology 2019. [CrossRef] 
52. Fajardo, J.; Waniska, R.; Cuero, R.; Pettit, R. Phenolic compounds in peanut seeds: Enhanced elicitation by chitosan and effects on growth and aflatoxin B1 production by Aspergillus flavus. Food Biotechnol. 1995, 9 , 59-78. [CrossRef]

53. Mandal, S.; Gupta, C. Inducing cell wall-bound phenolic compounds by elicitors in eggplant (Solanum melongena). Appl. Biochem. Microbiol. 2016, 52, 650-656. [CrossRef]

54. Skrzypczak-Pietraszek, E.; Słota, J.; Pietraszek, J. The influence of L-phenylalanine, methyl jasmonate and sucrose concentration on the accumulation of phenolic acids in Exacum affine Balf. f. ex Regel shoot culture. Acta Biochim. Pol. 2014, 61, 47-53. [CrossRef]

(C) 2019 by the authors. Licensee MDPI, Basel, Switzerland. This article is an open access article distributed under the terms and conditions of the Creative Commons Attribution (CC BY) license (http://creativecommons.org/licenses/by/4.0/). 